\title{
DINAMIKA KUALITAS UDARA AMBIEN SELAMA MASA \\ PANDEMI COVID-19 DI KAWASAN INDONESIA TOURISM DEVELOPMENT CORPORATION NUSA DUA BALI
}

\author{
Ika Sulistiani, I GD Yudha Partama*, Sang Putu Kaler Surata, I Ketut Sumantra \\ Program Studi Magister Perencanaan Pembangunan Wilayah dan Pengelolaan \\ Lingkungan Universitas Mahasaraswati Denpasar \\ *Email: yudhapartama46@gmail.com
}

\section{ABSTRACT \\ DYNAMICS OF AMBIENT AIR QUALITY DURING THE COVID- 19 PANDEMIC PERIOD IN INDONESIA TOURISM DEVELOPMENT CORPORATION NUSA DUA BALI}

The Covid-19 pandemic has increased the improvement of air quality in various countries in the world, such as China, Italy, New York, India, Spain and Korea. This study aims to compare ambient air quality during the Covid-19 pandemic with new normal and normal periods, assess the effect of meteorological factors on ambient air quality, and map the spatial distribution of ambient air quality during the normal, Covid-19 pandemic and new normal in the ITDC Nusa Dua area. Air concentration parameter data and meteorological factors were collected using the midget impinger and direct reading method in 2019 (normal period), March and May 2020 (Covid-19 pandemic period) and July, September, and November 2020 (new normal period). Furthermore, comparing air quality using the Anova test, assessing the effect of meteorological factors on air quality using a linear regression test, and mapping the distribution of ambient air using the ArcGis 10.8 application. The analysis showed that the air quality during the Covid-19 pandemic and the new normal was significantly different from the normal period. The concentrations of $\mathrm{SO}_{2}, \mathrm{NO}_{2}, \mathrm{NH}_{3}, \mathrm{CO}$, TSP and $\mathrm{H}_{2} \mathrm{~S}$ during the Covid-19 pandemic and normal just decreased while the $\mathrm{O}_{3}$ concentration increased compared to the normal period. The meteorological factor that affects air quality is the wind speed, the higher the wind speed the lower the $\mathrm{O}_{3}$ concentration. Map of the distribution of spatial concentrations of $\mathrm{SO}_{2}, \mathrm{NO}_{2}, \mathrm{NH}_{3}, \mathrm{CO}$, $\mathrm{O}_{3}$ and $\mathrm{H}_{2} \mathrm{~S}$ in the normal, Covid-19 pandemic and new normal, lowest at the coast point of the peninsula and the highest distribution at the ITDC roundabout, bima statue or influence TSP is the highest spatial concentration of normal distribution at the ITDC roundabout and the bima statue, while the Covid-19 pandemic and normal are only at the coast point of the peninsula beach.

Keywords: ambient air quality; Covid-19; pandemic; tourism.

\section{PENDAHULUAN}

Udara ambien yang sehari-hari disebut sebagai udara merupakan komponen kehidupan yang sangat penting untuk manusia dan mahkluk hidup lainnya seperti tumbuhan dan hewan. Seiring dengan meningkatnya pembangunan infrastruktur mulai dari sektor industri dan sektor transportasi yang terus meningkat menyebabkan kualitas udara menurun.

Sistem pengendalian terhadap penyebaran virus Covid-19 yang 
diterapkan pada beberapa negara telah menyebabkan berkurangnya aktivitas masyarakat yang berdampak terhadap kualitas udara di berbagai negara. Berdasarkan penelitian disebutkan bahwa pada beberapa negara di dunia khususnya dikawasan urban city telah mengalami peningkatan kualitas udara yang ditandai dengan menurunnya beberapa konsentrasi pencemar udara. Di negara Brazil tepatnya dikota Sao paulo diketahui telah mengalami penurunan drastis pada parameter $\mathrm{NO}$ hingga $77,3 \%, \mathrm{NO}_{2} 54,3 \%$, dan konsentrasi CO hingga $64,8 \%$ dibandingkan dengan konsentrasi rata-rata bulanan selama lima tahun terakhir dengan mengabaikan adanya pengaruh faktor lingkungan (Nakada \& Urban, 2020). Kondisi serupa juga terjadi di Negara Spanyol (Tobias et al., 2020), New York (Zangari et.al., 2020), India (Gautam, 2020) dan beberapa negara atau wilayah lainnya di dunia.

Kawasan Indonesia Tourism Bali Development (ITDC) Nusa Dua merupakan kawasan pariwisata berstandard internasional di Bali dan merupakan salah satu pengembangan destinasi pariwisata terbaik dunia (ITDC, 2020). Kawasan ITDC dikelola secara konsisten dengan konsep ramah lingkungan sehingga pemantauan kualitas udara secara berkala terutama selama masa pandemi Covid-19 sangat penting dilakukan untuk mengetahui konsentrasi polutan di udara seperti $\mathrm{SO}_{2}, \mathrm{NO}_{2}, \mathrm{CO}$, $\mathrm{O}_{3}, \mathrm{H}_{2} \mathrm{~S}, \mathrm{NH}_{3}$ dan partikulat.

Berdasarkan penjelasan tersebut diatas, maka penelitian kualitas udara ambien selama masa pandemi Covid-19 di Kawasan Indonesia Tourism Development Corporation (ITDC) Nusa Dua penting dilakukan dengan tujuan untuk mengetahui sejauh mana pengaruh pandemi Covid-19 dan faktor meteorologi terhadap kualitas udaranya serta memetakan sebaran spasialnya. Hasil penelitian ini diharapkan dapat dijadikan sebagai dasar dalam pengendalian dan manajemen lingkungan.

\section{METODOLOGI}

Desain penelitian. Penelitian ini menggunakan pendekatan kuantitatif (deskriptif dan inferensial) dengan desain survei longitudinal melalui beberapa kali koleksi data untuk memperoleh pola kecenderungan kualitas udara ambien, antara masa normal, masa pandemi Covid19 dan masa normal baru. Yang dimaksud dengan masa normal yaitu masa sebelum ditetapkannya masa pandemi Covid-19 oleh pemerintah pada bulan Maret 2020, masa pandemi Covid-19 yaitu masa pada bulan Maret sampai dengan Mei 2020 berdasarkan Kepres No. 12 Tahun 2020 dan masa normal baru yaitu masa pada bulan Juni sampai dengan Desember 2020 berdasarkan Surat Keputusan Menteri Dalam Negeri No. 440-830 Tahun 2020.

Waktu dan lokasi penelitian. Penelitian berlangsung mulai Agustus 2020 sampai Januari 2021 di Kawasan ITDC Nusa Dua Bali yang berlokasi di Kawasan Pariwisata Nusa Dua, Badung, Bali, Indonesia (Gambar 1). Kawasan Indonesia Tourism Bali Development (ITDC) Nusa Dua adalah salah satu kawasan pariwisata berstandard internasional di Bali dan merupakan salah satu pengembangan destinasi pariwisata terbaik dunia serta dikelola secara konsisten dengan konsep ramah lingkungan (ITDC, 2020). Data dikoleksi dari tiga titik sampling, yaitu titik Peninsula Beach pada titik koordinat $\left(08^{\circ}\right.$ $48^{\prime} 135^{\prime \prime}$ LS dan $115^{\circ} 14^{\prime} 252^{\prime \prime}$ BT), titik Patung Bima pada titik koordinat $\left(08^{\circ} 48^{\prime}\right.$ 384" LS dan $115^{\circ} 13^{\prime} 641^{\prime \prime}$ BT) dan titik Bundaran Kawasan ITDC Nusa Dua pada titik koordinat $\left(08^{\circ} 47^{\prime} 763^{\prime \prime}\right.$ LS dan $115^{\circ}$ 13' 641" BT). 


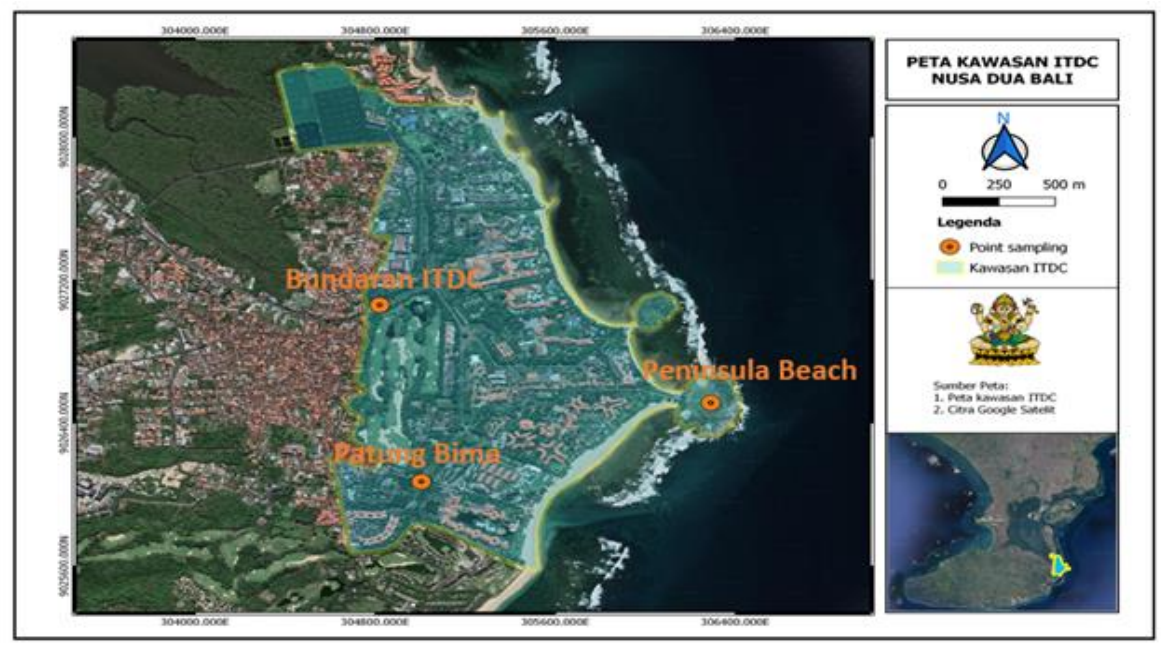

Gambar 1.

Peta Kawasan ITDC Nusa Dua Bali

Data penelitian. Data kualitas udara ambien $\left(\mathrm{SO}_{2}, \mathrm{NO}_{2}, \mathrm{O}_{3}, \mathrm{NH}_{3}, \mathrm{H}_{2} \mathrm{~S}, \mathrm{CO}\right.$ dan debu total) dan faktor meteorologi (suhu dan kelembaban, kecepatan angin dan curah hujan) pada masa normal dan pandemi Covid-19 merupakan data sekunder yang bersumber dari laporan hasil uji kualitas udara yang dikeluarkan oleh UPTD. Balai Hyperkes \& KK Dinas Ketenagakerjaan dan ESDM Provinsi Bali, yang diambil pada bulan Februari, April, Juni, Agustus, Oktober dan Desember 2019 (masa normal), Maret dan Mei 2020 (masa pandemi Covid-19). Sedangkan data kualitas udara masa normal baru merupakan campuran antara data sekunder (Juli dan September 2020) dan data primer (Nopember 2020) dengan menggunakan alat serta metode pengambilan sample yang sama.

Teknik koleksi data. Data primer konsentrasi $\mathrm{SO}_{2}, \mathrm{NO}_{2}, \mathrm{O}_{3}, \mathrm{NH}_{3}, \mathrm{H}_{2} \mathrm{~S}$ dikoleksi menggunakan alat midget impinger; konsentrasi $\mathrm{CO}$ menggunakan alat KIMO HQ-10 dan debu total menggunakan Dust-Trak. Pengamatan pada masa normal dilakukan sebanyak 6 (enam) kali, masa pandemi Covid-19 sebanyak 2 (dua) kali dan pada masa normal baru sebanyak 3 (tiga) kali. Parameter faktor meteorologi yang terdiri dari suhu dan kelembaban diukur menggunakan Quest Temp, kecepatan angin menggunakan anemometer dan curah hujan didapatkan dari data sekunder BMKG dari pos pemantauan Bandara I Gusti Ngurah Rai melalui https://dataonline.bmkg.go.id/. Data faktor meteorologi pada penelitian ini merupakan data yang didapat pada hari yang sama saat pengambilan sampel kualitas udara, antara lain: data meteorogi masa normal (Februari-Desember 2019), masa pandemi Covid-19 (Maret \& Mei 2020) dan masa normal baru (JuliNopember 2020).

Teknik analisis data. Data tentang meterologi dan kualitas udara ambien dipresentasikan secara deskriptif dalam bentuk Tabel dan Gambar. Data kualitas udara ambien dibandingkan dengan dengan baku mutu Peraturan Gubernur Bali No. 16 Tahun 2016 Tentang Baku Mutu Lingkungan Hidup dan Kriteria Baku Kerusakan Lingkungan Hidup. Analisis varian (ANOVA) digunakan untuk menganalisis ada/tidaknya signifikansi perbedaan kualitas udara ambien terdiri dari parameter $\mathrm{SO}_{2}, \mathrm{NO}_{2}$, $\mathrm{O}_{3}, \mathrm{NH}_{3}, \mathrm{H}_{2} \mathrm{~S}, \mathrm{CO}$, dan debu total antara masa normal, masa pandemi Covid-19 dan masa normal baru menggunakan SPSS 
versi IBM 26. Sampel yang dianalisis sebanyak 11 (sebelas) dan merupakan hasil rerata sampel yang diambil dari 3 (tiga) titik/lokasi. Sedangkan regresi linear berganda digunakan untuk menganalisis pengaruh faktor meteorologi terhadap kualitas udara selama masa pandemi Covid-19. Peta sebaran spatial kualitas udara ambien divisualisasikan dengan teknik interpolasi data spasial kriging pada Sistem Informasi Geografis menggunakan aplikasi Software ArcGIS versi 10.8 (ESRI, 2020). Teknik interpolasi data spasial pada software ArcGIS 10.8 dilakukan dengan menjalankan fungsi dari tool "Raster Interpolation". Interpolasi data spasial menggunakan metode interpolasi kriging terhadap masing-masing parameter udara ambien yang terdiri dari 3 (tiga) data dan terdistribusi pada 3 (tiga) titik/lokasi sampling. Interpolasi dilakukan pada masa normal, pandemi Covid-19, dan normal baru.

Teknik sampling. Penentuan lokasi pengambilan sampel udara ambien mengacu pada SNI 19-7119-6: 2005 tentang penentuan lokasi pengambilan contoh uji pemantauan kualitas udara ambien (Badan Standarisasi Nasional, 2005a). Pengukuran konsentrasi $\mathrm{SO}_{2}$ udara ambien mengacu pada SNI 71197:2017 dengan metode pararosanillin menggunakan spektrofotometer UV-VIS (Badan Standarisasi Nasional, 2017b). Pengukuran konsentrasi $\mathrm{NO}_{2}$ udara ambien mengacu pada SNI 7119-2:2017 dengan metode Griess Saltzman menggunakan spektrofotometer UV-VIS (Badan Standarisasi Nasional, 2017a). Pengukuran konsentrasi $\mathrm{O}_{3}$ udara ambien mengacu pada SNI 7119-8:2017 dengan metode neutral buffer kalium iodide (NBKI) menggunakan spektrofotometer UV-VIS(Badan Standarisasi Nasional, 2017c) . Pengukuran konsentrasi $\mathrm{NH}_{3}$ udara ambien mengacu pada SNI 71191:2005 dengan metode Indofenol menggunakan spektrofotometer UV-VIS (Badan Standarisasi Nasional, 2005b). Pengukuran konsentrasi $\mathrm{H}_{2} \mathrm{~S}$ udara ambien mengacu pada SNI 8605:2018 dengan metode biru metilen menggunakan spektrofotometer UV-VIS (Badan Standarisasi Nasional, 2018). Pengukuran konsentrasi debu total udara ambien, $\mathrm{CO}$, suhu, kelembaban, dan kecepatan angin mengacu pada Instruksi Kerja UPTD. Balai Hyperkes \& KK (Hyperkes Bali, 2018).

\section{HASIL DAN PEMBAHASAN}

\subsection{Hasil}

\subsubsection{Kualitas Udara Ambien Pada Masa Pandemi Covid-19 Dibandingkan Dengan Masa Normal Dan Normal Baru}

Hasil uji kualitas udara memperlihatkan bahwa konsentrasi parameter $\mathrm{SO}_{2}, \mathrm{NO}_{2}, \mathrm{CO}, \mathrm{NH}_{3}, \mathrm{H}_{2} \mathrm{~S}$ dan debu total selama masa pandemi Covid-19 dan normal baru menurun, dan sebaliknya konsentrasi $\mathrm{O}_{3}$ mengalami kenaikan dibandingkan dengan masa normal (Gambar 2).

Hasil uji anova (Tabel 1) menunjukkan bahwa nilai signifikansi konsentrasi $\mathrm{SO}_{2}, \mathrm{NO}_{2}, \mathrm{O}_{3}, \mathrm{CO}$, debu total dan $\mathrm{H}_{2} \mathrm{~S}$ pada masa normal, pandemi Covid-19 dan normal baru lebih kecil dari $0,05(\mathrm{P}<0,05)$ yang menjelaskan bahwa konsentrasi $\mathrm{SO}_{2}, \mathrm{NO}_{2}, \mathrm{O}_{3}, \mathrm{CO}$, debu total dan $\mathrm{H}_{2} \mathrm{~S}$ masa normal dibandingkan dengan masa pandemi Covid-19 dan normal baru berbeda nyata. Sedangkan nilai signifikansi konsentrasi $\mathrm{NH}_{3}$ lebih besar dari $0,05 \quad(\mathrm{P}>0,05) \quad$ yang menjelaskan bahwa konsentrasi $\mathrm{NH}_{3}$ selama masa normal, pandemi Covid-19 dan normal baru tidak berbeda nyata. 


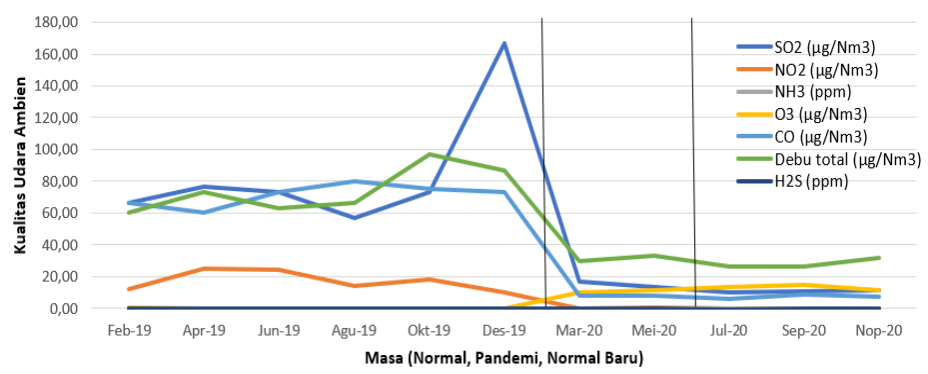

Gambar 2.

Kecenderungan Kualitas Udara Ambien Selama Masa Normal, Pandemi Covid-19 Dan Normal Baru

Hasil uji lanjutan anova (post hoc test) $\mathrm{SO}_{2}, \mathrm{NO}_{2}, \mathrm{H}_{2} \mathrm{~S}, \mathrm{CO}$ dan debu total masa menunjukkan bahwa nilai rata-rata pandemi Covid-19 dan normal baru konsentrasi $\mathrm{SO}_{2}, \mathrm{NO}_{2}, \mathrm{H}_{2} \mathrm{~S}, \mathrm{CO}$ dan debu berbeda nyata dengan masa normal. total selama masa pandemi Covid-19 Hanya konsentrasi $\mathrm{O}_{3}$ pada masa normal, dibandingkan dengan normal baru tidak pandemi Covid-19 dan normal baru berbeda nyata, sebaliknya konsentrasi berbeda nyata.

Tabel 1. Hasil Uji Anova Dan Uji Lanjutan Duncan

\begin{tabular}{|c|c|c|c|c|c|}
\hline Parameter & $\begin{array}{l}\text { Normal } \\
\text { Uji Lanjutan Duncan }\end{array}$ & $\begin{array}{l}\text { Pandemi } \\
\text { Covid-19 }\end{array}$ & Normal baru & $\begin{array}{l}\text { Baku } \\
\text { Mutu }\end{array}$ & $\begin{array}{l}\text { Uji } \\
\text { Anova } \\
\text { (Sig) }\end{array}$ \\
\hline $\begin{array}{l}\mathrm{SO}_{2} \\
\left(\mu \mathrm{g} / \mathrm{Nm}^{3}\right)\end{array}$ & $\begin{array}{l}85,56 \pm 40,37 \\
\text { a }\end{array}$ & $\begin{array}{l}15,00 \pm 2,36 \\
b\end{array}$ & $\begin{array}{l}10.89 \pm 0,84 \\
b\end{array}$ & 900 & 0,016 \\
\hline $\begin{array}{l}\mathrm{NO}_{2} \\
\left(\mu \mathrm{g} / \mathrm{Nm}^{3}\right)\end{array}$ & $\begin{array}{l}17,39 \pm 6,25 \\
\mathrm{a}\end{array}$ & $\begin{array}{l}0,32 \pm 0,02 \\
b\end{array}$ & $\begin{array}{l}0.16 \pm 0,05 \\
b\end{array}$ & 400 & 0,017 \\
\hline $\mathrm{NH}_{3}(\mathrm{ppm})$ & $\begin{array}{l}0,05 \pm 0,01 \\
\mathrm{a}\end{array}$ & $\begin{array}{l}0.02 \pm 0 \\
\mathrm{a}\end{array}$ & $\begin{array}{l}0.01 \pm 0 \\
\mathrm{a}\end{array}$ & 2 & 0,199 \\
\hline $\begin{array}{l}\mathrm{O}_{3} \\
\left(\mu \mathrm{g} / \mathrm{Nm}^{3}\right)\end{array}$ & $\begin{array}{l}0,10 \pm 0,13 \\
\mathrm{a}\end{array}$ & $\begin{array}{l}11.00 \pm 0,94 \\
\mathrm{~b}\end{array}$ & $\begin{array}{l}13.44 \pm 1,68 \\
\text { c }\end{array}$ & 235 & 0,018 \\
\hline $\begin{array}{l}\mathrm{CO} \\
\left(\mu \mathrm{g} / \mathrm{Nm}^{3}\right)\end{array}$ & $\begin{array}{l}71,39 \pm 7,03 \\
\mathrm{a}\end{array}$ & $\begin{array}{l}8.33 \pm 0 \\
b\end{array}$ & $\begin{array}{l}7.44 \pm 1,5 \\
b\end{array}$ & 30.000 & 0,022 \\
\hline $\begin{array}{l}\text { Debu total } \\
\left(\mu \mathrm{g} / \mathrm{Nm}^{3}\right)\end{array}$ & $\begin{array}{l}74,44 \pm 14,4 \\
\mathrm{a}\end{array}$ & $\begin{array}{l}31.67 \pm 2,36 \\
\text { b }\end{array}$ & $\begin{array}{l}28.33 \pm 2,89 \\
b\end{array}$ & 230 & 0,02 \\
\hline $\mathrm{H}_{2} \mathrm{~S}(\mathrm{ppm})$ & $\begin{array}{l}0,006 \pm 0 \\
\mathrm{a}\end{array}$ & $\begin{array}{l}0.002 \pm 0 \\
b\end{array}$ & $\begin{array}{l}0.002 \pm 0 \\
b\end{array}$ & 0,02 & 0,016 \\
\hline
\end{tabular}

Keterangan: Uji Anova: $\mathrm{P}=0,05$

Baku mutu kualitas udara ambien berdasarkan Peraturan Gubernur Bali No. 16 Tahun 2016 Uji lanjut Duncan: kode dengan huruf yang sama menunjukkan bahwa kualitas udara tidak berbeda nyata pada taraf $5 \%$

\subsubsection{Pengaruh Faktor Meteorologi Dan Tingkat Hunian Hotel Terhadap Kualitas Udara Ambien}

Suhu udara ambien selama masa normal, pandemi Covid-19 dan normal baru berkisar antara $29-30^{\circ} \mathrm{C}$. Kelembaban berkisar antara 70-77,33 \%; kecepatan angin berkisar antara 2,33-8 $\mathrm{m} / \mathrm{dt}$ dan curah hujan berkisar antara 0-1 mm. Data faktor meteorologi dan tingkat hunian hotel diperlihatkan dalam Gambar 3 dan 4. 


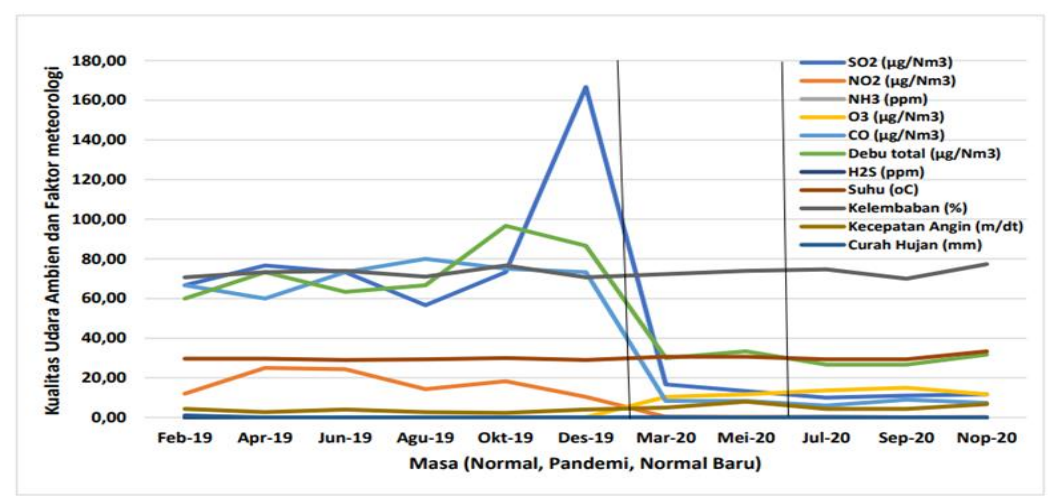

Gambar 3.

Grafik Data Perbandingan Antara Kualitas Udara Dan Faktor Meteorologi

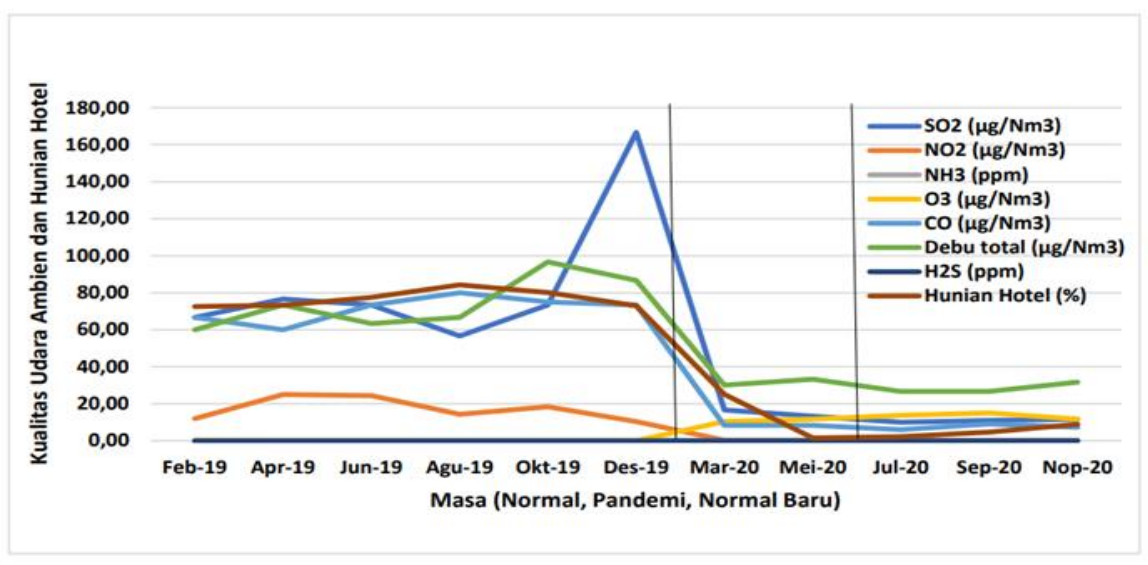

Gambar 4.

Grafik Data Perbandingan Kualitas Udara Dan Hunian Hotel

Berdasarkan hasil analisis uji F (Tabel 2) menunjukkan bahwa nilai signifikansi F suhu, kelembaban, kecepatan angin, curah hujan dan tingkat hunian hotel terhadap konsentrasi $\mathrm{NO}_{2}, \mathrm{NH}_{3}, \mathrm{O}_{3}, \mathrm{CO}$, debu total dan $\mathrm{H}_{2} \mathrm{~S}$ adalah lebih kecil dari $0,05(\mathrm{P}<0,05)$, sedangkan terhadap $\mathrm{SO}_{2}$ lebih besar dari $0,05(\mathrm{P}>0,05)$. Hal ini dapat diartikan bahwa faktor meteorologi (suhu, kelembaban, kecepatan angin, curah hujan) dan tingkat hunian hotel secara simultan berpengaruh terhadap kualitas udara $\mathrm{NO}_{2}, \mathrm{NH}_{3}, \mathrm{O}_{3}, \mathrm{CO}$, debu total dan $\mathrm{H}_{2} \mathrm{~S}$ namun tidak berpengaruh terkadap $\mathrm{SO}_{2}$.

Hasil analisis uji $\mathrm{T}$ (Tabel 2) menunjukkan bahwa nilai signifikansi suhu, kelembaban, dan curah hujan terhadap $\mathrm{SO}_{2}, \mathrm{NO}_{2}, \mathrm{NH}_{3}, \mathrm{O}_{3}, \mathrm{CO}$, debu total dan $\mathrm{H}_{2} \mathrm{~S}$ adalah lebih besar dari 0,05 ( $\mathrm{P}>0,05)$. Hal ini dapat diartikan bahwa faktor meteorologi suhu, kelembaban, dan curah hujan secara parsial tidak berpengaruh terhadap kualitas udara terhadap $\mathrm{SO}_{2}, \mathrm{NO}_{2}, \mathrm{NH}_{3}, \mathrm{O}_{3}, \mathrm{CO}$, debu total dan $\mathrm{H}_{2} \mathrm{~S}$.

Nilai signifikansi kecepatan angin terhadap $\mathrm{SO}_{2}, \mathrm{NO}_{2}, \mathrm{NH}_{3}, \mathrm{CO}$, debu total dan $\mathrm{H}_{2} \mathrm{~S}$ lebih besar dari 0,05 $(\mathrm{P}>0,05)$ sedangkan nilai signifikansi terhadap konsentrasi $\mathrm{O}_{3}$ lebih kecil dari 0,05 $(\mathrm{P}<0,05)$ dengan nilai koefisien regresi sebesar -0,784. Hasil uji Tersebut menunjukkan bahwa kecepatan angin secara parsial tidak berpengaruh nyata terhadap konsentrasi $\mathrm{SO}_{2}, \mathrm{NO}_{2}, \mathrm{NH}_{3}, \mathrm{CO}$, debu total dan $\mathrm{H}_{2} \mathrm{~S}$ namun berpengaruh negatif (asumsi nilai konstanta a adalah 0 ) 
terhadap konsentrasi $\mathrm{O}_{3}$ sebesar 0,784 . Hal ini dapat diartikan bahwa semakin besar kecepatan angin maka konsentrasi $\mathrm{O}_{3}$ akan menurun.

Nilai signifikansi tingkat hunian hotel terhadap konsentrasi $\mathrm{SO}_{2}$ lebih besar dari $0,05 \quad(\mathrm{P}>0,05) \quad$ sedangkan terhadap konsentrasi $\mathrm{NO}_{2}, \mathrm{NH}_{3}, \mathrm{O}_{3}, \mathrm{CO}$, debu total dan $\mathrm{H}_{2} \mathrm{~S}$ lebih kecil dari $0,05 \quad(\mathrm{P}<0,05)$ dengan nilai koefisien regresi $\mathrm{NO}_{2}$ sebesar 0,$236 ; \mathrm{NH}_{3}$ sebesar 0,$01 ; \mathrm{O}_{3}$ sebesar 0,202 ; CO sebesar 0,943 ; debu total sebesar 0,656 dan $\mathrm{H}_{2} \mathrm{~S}$ sebesar $6 \times 10^{-5}$. Hasil analisis tersebut menunjukkan bahwa hunian hotel secara parsial tidak berpengaruh nyata terhadap konsentrasi $\mathrm{SO}_{2}$ namun berpengaruh positif terhadap konsentrasi $\mathrm{NO}_{2}$ sebesar 0,236; terhadap $\mathrm{NH}_{3}$ sebesar 0,$01 ; 02$; terhadap $\mathrm{CO}$ sebesar 0,943; terhadap debu total sebesar 0,656 dan terhadap $\mathrm{H}_{2} \mathrm{~S}$ sebesar $6 \times 10^{-5}$ dan berpengaruh negatif terhadap $\mathrm{O}_{3}$ sebesar 0,2 (asumsi nilai konstanta a adalah 0). Hal ini dapat diartikan bahwa semakin tinggi tingkat hunian hotel, maka konsentrasi $\mathrm{NO}_{2}, \mathrm{NH}_{3}, \mathrm{CO}$, debu total dan $\mathrm{H}_{2} \mathrm{~S}$ akan meningkat dan konsentrasi $\mathrm{O} 3$ semakin menurun. Hasil uji $\mathrm{F}$ dan Uji $\mathrm{T}$ regresi linear berganda selengkapnya pada Tabel 2. Pengaruh faktor meteorologi terhadap kualitas udara ambien selengkapnya ditunjukkan oleh persamaan regresi pada Tabel 3 .

Tabel 2. Hasil uji $\mathrm{F}$ dan uji $\mathrm{T}$ pengaruh faktor meteorologi, hunian hotel terhadap kualitas udara

\begin{tabular}{llllllll}
\hline No & $\begin{array}{l}\text { Variabel } \\
\text { Terikat }\end{array}$ & $\begin{array}{l}\text { Uji F } \\
\text { (Sig) }\end{array}$ & Suhu & Kelembaban & $\begin{array}{l}\text { Uji T (Sig) } \\
\text { Kecepatan } \\
\text { angin }\end{array}$ & $\begin{array}{l}\text { Curah } \\
\text { hujan }\end{array}$ & $\begin{array}{l}\text { Hunian } \\
\text { hotel }\end{array}$ \\
\hline 1 & $\mathrm{SO}_{2}$ & 0,229 & 0,672 & 0,735 & 0,465 & 0,528 & 0,63 \\
2 & $\mathrm{NO}_{2}$ & 0,035 & 0,372 & 0,235 & 0,891 & 0,682 & 0,020 \\
3 & $\mathrm{NH}_{3}$ & 0,008 & 0,116 & 0,394 & 0,095 & 0,208 & 0,002 \\
4 & $\mathrm{O}_{3}$ & 0,000 & 0,408 & 0,249 & 0,043 & 0,723 & 0,000 \\
5 & $\mathrm{CO}$ & 0,010 & 0,251 & 0,656 & 0,342 & 0,702 & 0,000 \\
6 & Debu total & 0,033 & 0,696 & 0,451 & 0,890 & 0,509 & 0,014 \\
7 & $\mathrm{H}_{2} \mathrm{~S}$ & 0,017 & 0,709 & 0,915 & 0,311 & 0,464 & 0,004 \\
\hline
\end{tabular}

Keterangan: $\mathrm{P}=0,05$

Tabel 3. Persamaan regresi kualitas udara (Y) dengan varibel faktor meteorologi dan hunian hotel (X)

\begin{tabular}{llll}
\hline No & $\begin{array}{l}\text { Variabel } \\
\text { Terikat }(\mathrm{Y})\end{array}$ & $\mathrm{R}^{2}$ & Persamaan Regresi Linear \\
\hline 1 & $\mathrm{SO}_{2}$ & 0,669 & $\mathrm{Y}=351,771-7,178 \mathrm{X}_{1}-2,452 \mathrm{X}_{2}+9,802 \mathrm{X}_{3}+30,003 \mathrm{X}_{4}+1,226 \mathrm{X}_{5}$ \\
2 & $\mathrm{NO}_{2}$ & 0,858 & $\mathrm{Y}=30,305-2,150 \mathrm{X}_{1}-1,269 \mathrm{X}_{2}+0,244 \mathrm{X}_{3}-2,464 \mathrm{X}_{4}+0,236 \mathrm{X}_{5}$ \\
3 & $\mathrm{NH}_{3}$ & 0,926 & $\mathrm{Y}=0,081-0,07 \mathrm{X}_{1}+0,001 \mathrm{X}_{2}+0,006 \mathrm{X}_{3}-0,015 \mathrm{X}_{4}+0,01 \mathrm{X}_{5}$ \\
4 & $\mathrm{O}_{3}$ & 0,990 & $\mathrm{Y}=23,627+0,337 \mathrm{X}_{1}-0,209 \mathrm{X}_{2}-0,784 \mathrm{X}_{3}-0,388 \mathrm{X}_{4}-0,202 \mathrm{X}_{5}$ \\
5 & $\mathrm{CO}$ & 0,975 & $\mathrm{Y}=63,366-4,014 \mathrm{X}_{1}+0,626 \mathrm{X}_{2}+2,52 \mathrm{X}_{3}-3,473 \mathrm{X}_{4}+0,943 \mathrm{X}_{5}$ \\
6 & Debu total & 0,862 & $\mathrm{Y}=50,403-2,290 \mathrm{X}_{1}+1,939 \mathrm{X}_{2}+0,624 \mathrm{X}_{3}-10,914 \mathrm{X}_{4}+0,656 \mathrm{X}_{5}$ \\
7 & $\mathrm{H}_{2} \mathrm{~S}$ & 0,896 & $\mathrm{Y}=0,003+0,0 \mathrm{X}_{1}+\left(2 \mathrm{x}^{-5}\right) \mathrm{X}_{2}+0,0 \mathrm{X}_{3}-0,01 \mathrm{X}_{4}+\left(6 \mathrm{x}_{1} 0^{-5}\right) \mathrm{X}_{5}$ \\
\hline
\end{tabular}

Keterangan:

suhu $\left(\mathrm{X}_{1}\right)$, kelembaban $\left(\mathrm{X}_{2}\right)$, kecepatan angin $\left(\mathrm{X}_{3}\right)$, curah hujan $\left(\mathrm{X}_{4}\right)$, hunian hotel $\left(\mathrm{X}_{5}\right)$.

Nilai variabel bebas $(\mathrm{Y})$ dipengaruhi oleh nilai koefisien variabel terikat $(\mathrm{X})$ dengan asumsi nilai konstanta adalah 0 (nol). 


\subsubsection{Peta Sebaran Spasial Kualitas Udara Ambien Berdasarkan Sistem Informasi Geografis}

Sebaran konsentrasi CO pada masa normal dan pandemi Covid-19 tersebar dari konsentrasi tinggi ke rendah diperlihatkan pada titik bundaran ITDC dan patung bima dengan hasil tingkat sebaran yang sama, sedangkan sebaran terendah berada pada titik peninsula beach. Pada masa normal baru, sebaran konsentrasi tertinggi berada pada titik bundaran ITDC disusul oleh titik patung bima dan peninsula beach (Gambar 3). Konsentrasi sebaran $\mathrm{CO}$ dari rendah ketinggi adalah masa normal 22,52-96,64 $\mu \mathrm{g} / \mathrm{Nm}^{3}$; masa pandemi Covid-19 5,00$10,00 \mu \mathrm{g} / \mathrm{Nm}^{3}$; dan masa normal baru $3,00-10,33 \mu \mathrm{g} / \mathrm{Nm}^{3}$.

Sebaran konsentrasi $\mathrm{NO}_{2}$ pada masa normal, pandemi Covid-19 dan normal baru tersebar dari konsentrasi tinggi ke rendah diperlihatkan pada titik bundaran ITDC dan patung bima. Sebaran terendah konsentrasi $\mathrm{NO}_{2}$ berada pada titik peninsula beach (Gambar 4). Konsentrasi sebaran $\mathrm{NO}_{2}$ dari rendah ketinggi adalah masa normal 3,84-26,66 $\mu \mathrm{g} / \mathrm{Nm}^{3}$; masa pandemi Covid-19 0,15-0,40 $\mu \mathrm{g} / \mathrm{Nm}^{3}$; dan masa normal baru $0,13-0,15 \mu \mathrm{g} / \mathrm{Nm}^{3}$.

Sebaran konsentrasi $\mathrm{NH}_{3}$ pada masa normal, pandemi Covid-19 dan normal baru terlihat berbeda. Sebaran $\mathrm{NH}_{3}$ pada masa normal tertinggi di titik patung bima disusul oleh titik bundaran ITDC dan kemudian di titik peninsula beach. Pada masa pandemi Covid-19 sebaran tertinggi pada titik bundaran ITDC dan patung bima serta disusul oleh titik peninsula beach. Sebaran tertinggi pada masa normal baru berada pada titik bundaran ITDC dan disusul oleh titik patung bima dan peninsula beach (Gambar 5). Konsentrasi sebaran $\mathrm{NH}_{3}$ dari rendah ketinggi adalah masa normal 0,010-0,013 ppm; masa pandemi Covid-19 0,0100,020 ppm; dan masa normal baru 0,010$0,013 \mathrm{ppm}$.
Sebaran konsentrasi $\mathrm{H}_{2} \mathrm{~S}$ pada masa normal tertinggi pada titik bundaran ITDC dan patung bima dan disusul oleh peninsula beach. Pola sebaran ini sama denga pola sebaran pada masa normal baru. Sebaran pada masa pandemi Covid19 tertinggi pada titik patung bima dan disusul oleh titik bundaran ITDC dan peninsula beach (Gambar 6). Konsentrasi sebaran $\mathrm{H}_{2} \mathrm{~S}$ dari rendah ketinggi adalah masa normal 0,002-0,007 ppm; masa pandemi Covid-19 0,002-0,003 ppm; dan masa normal baru 0,001-0,002 ppm.

Pola sebaran konsentrasi $\mathrm{O}_{3}$ pada masa normal dan normal baru adalah sama pada ketiga titik sampling. Sebaran konsentrasi $\mathrm{O}_{3}$ pada masa pandemi Covid-19, tersebar merata pada ketiga titik(Gambar 7). Konsentrasi sebaran $\mathrm{O}_{3}$ dari rendah ketinggi adalah masa normal 0,032-0,17 $\mu \mathrm{g} / \mathrm{Nm}^{3}$; masa pandemi Covid-19 8,43$13,00 \mu \mathrm{g} / \mathrm{Nm}^{3}$; dan masa normal baru $12,35-14,65 \mu \mathrm{g} / \mathrm{Nm}^{3}$.

Sebaran konsentrasi $\mathrm{SO}_{2}$ pada masa normal tertinggi pada titik patung bima dan disusul oleh peninsula beach. Pola sebaran pada masa pandemi Covid-19 merata di ketiga titik. Sebaran pada masa normal baru tertinggi pada titik patung bima dan titik bundaran ITDC sedangkan sebaran terendah berada dititik peninsula beach (Gambar 8). Konsentrasi sebaran $\mathrm{SO}_{2}$ dari rendah ketinggi adalah masa normal 58,35-103,3 $\mu \mathrm{g} / \mathrm{Nm}^{3}$; masa pandemi Covid-19 10,7-18,05 $\mu \mathrm{g} / \mathrm{Nm}^{3}$; dan masa normal baru 9,33-11,67 $\mu \mathrm{g} / \mathrm{Nm}^{3}$.

Sebaran konsentrasi debu total pada masa normal tertinggi pada titik patung bima disusul titik bundaran ITDC dan peninsula beach. Pada masa pandemi Covid-19 sebaran debu total tertinggi pada titik peninsula beach dan sebaran terendah berada pada titik patung bima dan bundaran ITDC. Sebaran tertinggi pada masa normal baru berada pada titik peninsula beach yang disusul oleh titik patung bima dan bundaran ITDC (Gambar 9). Konsentrasi sebaran debu total dari 
rendah ketinggi adalah masa normal $66,67-80,00 \mu \mathrm{g} / \mathrm{Nm}^{3}$; masa pandemi
Covid-19 20,03-52,50 $\mu \mathrm{g} / \mathrm{Nm}^{3}$; dan masa normal baru $18,34-38,33 \mu \mathrm{g} / \mathrm{Nm}^{3}$.

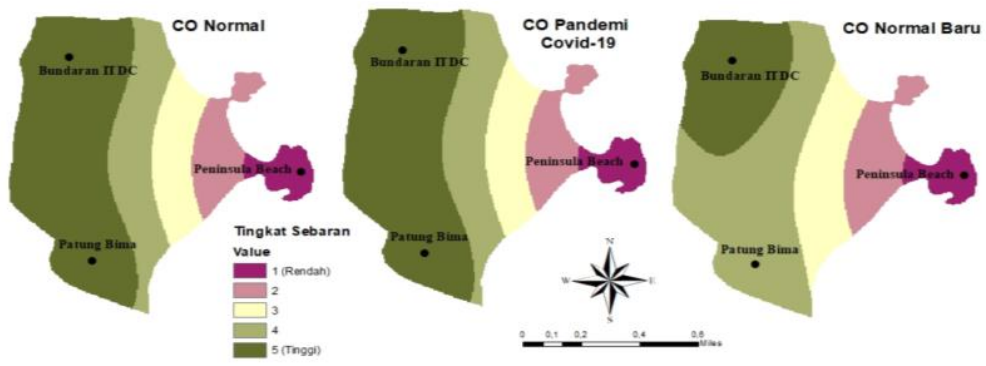

Gambar 3.

Peta Sebaran Spasial Parameter CO

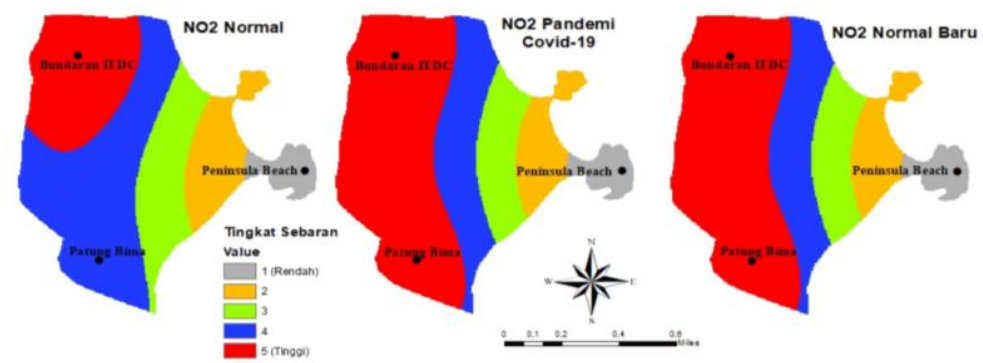

Gambar 4.

Peta Sebaran Spasial Parameter $\mathrm{NO}_{2}$

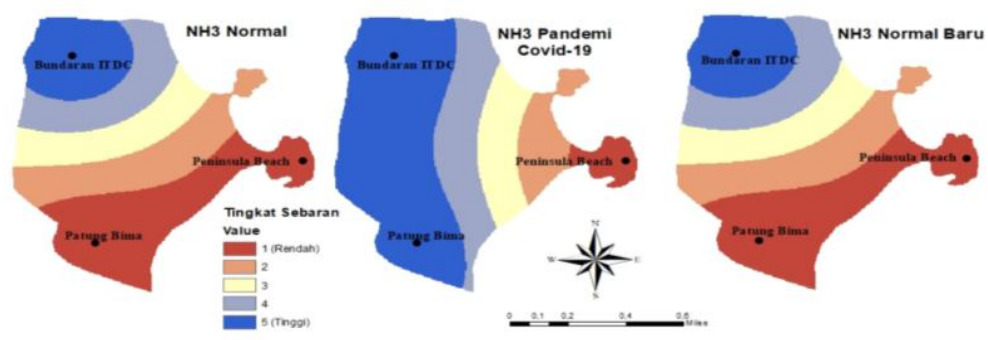

Gambar 5.

Peta Sebaran Spasial Parameter $\mathrm{NH}_{3}$
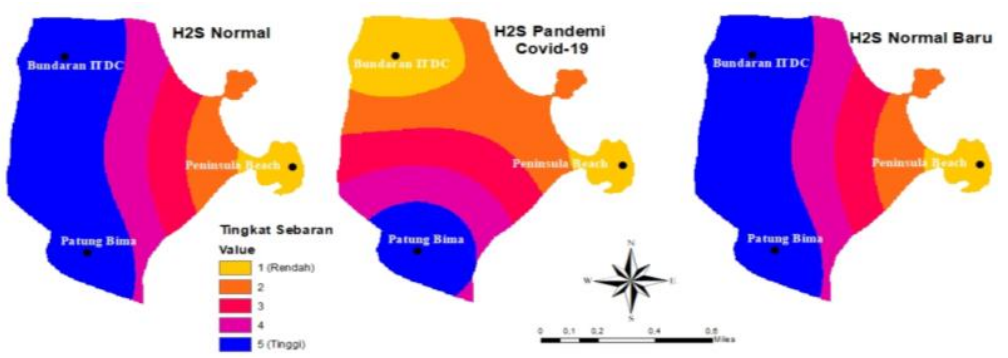

Gambar 6.

Peta Sebaran Spasial Parameter $\mathrm{H}_{2} \mathrm{~S}$ 


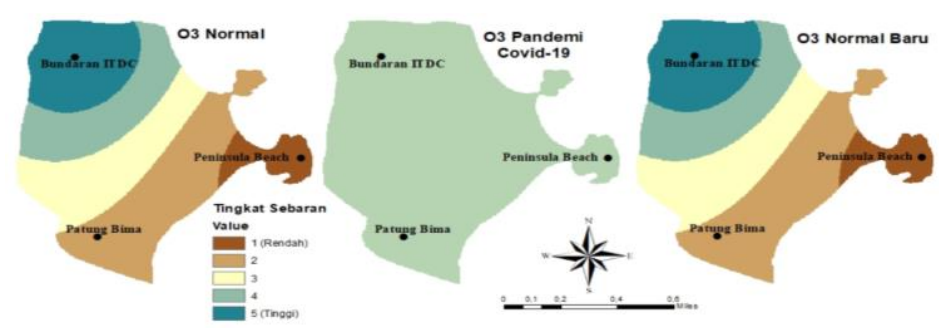

Gambar 7.

Peta Sebaran Spasial Parameter $\mathrm{O}_{3}$

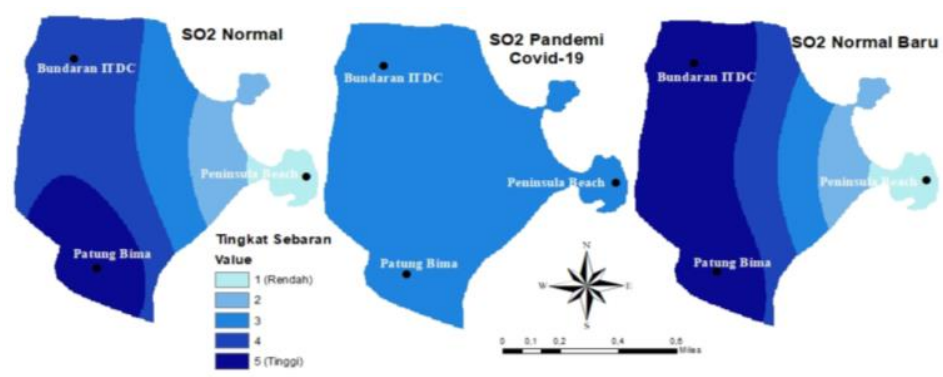

Gambar 8.

Peta Sebaran Spasial Parameter $\mathrm{SO}_{2}$

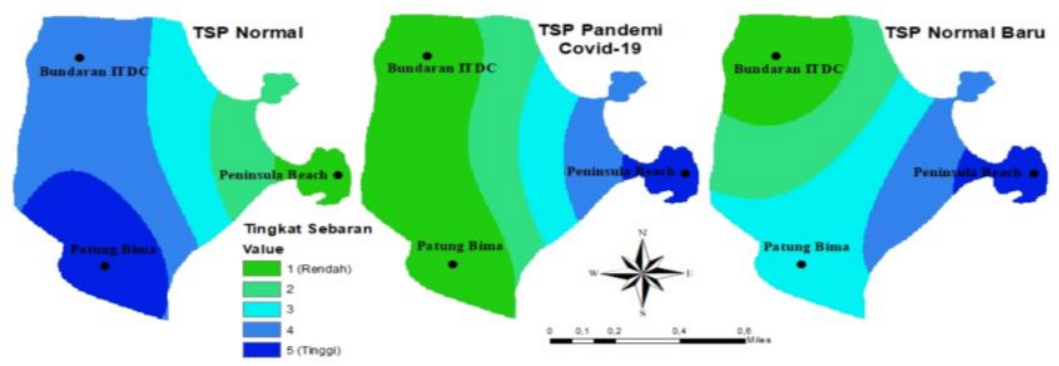

Gambar 9.

Peta Sebaran Spasial Parameter TSP

\subsection{Pembahasan}

Berdasarkan hasil penelitian, kualitas udara di Kawasan ITDC Nusa Dua Bali selama masa pandemi Covid-19 dan normal baru lebih baik dibandingkan dengan masa normal. Peningkatan kualitas udara tersebut terbukti dengan adanya menurunnya konsentrasi beberapa parameter pencemar udara seperti $\mathrm{SO}_{2}$, $\mathrm{NO}_{2}, \mathrm{CO}, \mathrm{NH}_{3}, \mathrm{H}_{2} \mathrm{~S}$ dan debu total. Kondisi berbeda terjadi pada konsentrasi parameter $\mathrm{O}_{3}$, dimana selama masa pandemi Covid-19 dan normal baru mengalami peningkatan dibandingkan dengan masa normal. Peningkatan konsentrasi $\mathrm{O}_{3}$ ini disebabkan oleh menurunnya jumlah parameter NO yang bereaksi dengan radikal peroksi diudara membentuk $\mathrm{NO}_{2}$. Radikal peroksi ini akan bereaksi dengan radikal peroksi lain (terisomerisasi) sehingga meningkatkan konsentrasi $\mathrm{O}_{3}$ (Kroll, 2020).

Hasil penelitian kualitas udara ambien selama masa pandemi Covid-19 dan normal baru di Kawasan ITDC Nusa Dua Bali ini sejalan dengan penelitian yang telah dilakukan di beberapa negara seperti di Negara Spanyol (Tobias et al., 2020), New York (Zangari et.al., 2020) dan India (Gautam, 2020). Penelitian tersebut menyimpulkan bahwa penurunan 
konsentrasi $\mathrm{NO}_{\mathrm{x}}$, NO dan PM10 di Spanyol, New York dan India disebabkan karena adanya penurunan aktivitas masyarakat akibat diterapkannya lockdown.

Meningkatnya kualitas udara di Kawasan ITDC Nusa Dua Bali disebabkan karena menurunnya aktivitas masyarakat terutama aktivitas wisata akibat adanya kebijakan pembatasan kegiatan masyarakat baik di Indonesia maupun negara lainnya. Selama masa pandemi Covid-19, jumlah wisatawan yang berkunjung ke Bali mengalami penurunan dibandingkan dengan sebelum pandemi Covid-19. Berdasarkan data Badan Pusat Statistik Provinsi Bali (2021), jumlah wisatawan ke Bali tahun 2020 menurun hingga lebih dari 100\% jika dibandingkan dengan tahun 2019.

Data ITDC (2020) menyebutkan bahwa jumlah wisatawan yang berkunjung selama masa pandemi Covid-19 dan normal baru (Maret-Oktober 2020) dibandingkan dengan masa normal (Maret-Oktober 2019) mengalami penurunan yang nyata. Jumlah wisatawan bulan Maret 2020 menurun hingga $65,64 \%$ sedangkan pada bulan April sampai dengan Oktober 2020 menurun 90 $-99,43 \%$.

Penurunan jumlah wisatawan ke ITDC Nusa Dua menyebabkan terjadinya penurunan aktivitas pariwisata yang terdiri dari aktivitas perhotelan dan transportasi. Berkurangkan aktivitas pariwisata ini menyebabkan terjadinya penurunan jumlah emisi udara yang bersumber dari kendaraan bermotor, aktivitas genset dan boiler hotel serta aktivitas manusia lainnya. Hal itu disebabkan kendaraan bermotor menyumbang kurang lebih NOx sebesar 71\%, SOx sebesar 15\% dan PM10 sebesar 70\% (Ismiyati, 2014). Sedangkan, pembakaran bahan bakar minyak dan batubara oleh penyedia daya listrik dan sarana transportasi akan menghasilkan emisi gas buang sebagai produk samping akibat pembakaran tidak sempurna (Juliasari \& Fathkurrahman, 2014). Sumber pencemar udara selain berasal dari aktivitas industri dan kendaraan bermotor, juga disebakan karena aktivitas manusia dan alam (Kroll, 2020). Hal ini juga sesuai dengan hasil uji regresi pengaruh tingkat hunian hotel di Kawasan ITDC terhadap udara ambien pada penelitian ini, dimana semakin tinggi tingkat hunian hotel maka akan konsentrasi $\mathrm{NO}_{2}, \mathrm{NH}_{3}, \mathrm{O}_{3}, \mathrm{CO}$, debu total dan $\mathrm{H}_{2} \mathrm{~S}$ akan meningkat namun konsentrasi $\mathrm{O}_{3}$ akan menurun.

Penelitian ini menemukan bahwa kecepatan angin berpengaruh terhadap konsentrasi $\mathrm{O}_{3}$. Hal ini disebabkan karena kecepatan angin bersifat fluktuatif akibat dipengaruhi dari topografi pada masingmasing wilayah yang tentunya berpengaruh juga terhadap persebaran polutan (Marhaeni, 2018). Turyanti (2011) juga menyatakan bahwa pengaruh faktor meteorologi terhadap kualitas udara berbeda tergantung jenis zat pencemar dan lokasi pengambilan sampel.

Hasil interpolasi kriging terhadap konsentrasi $\mathrm{SO}_{2}, \mathrm{NO}_{2}, \mathrm{NH}_{3}, \mathrm{O}_{3}, \mathrm{CO}$, dan $\mathrm{H}_{2} \mathrm{~S}$ pada penelitian ini menunjukkan bahwa sebaran terendah selama masa normal, pandemi Covid-19 dan normal baru berada pada titik peninsula beach. Hal ini disebaban karena lokasi tersebut berada di dekat pantai dan area terbuka sehingga memungkinkan terjadinya sebaran gas lebih cepat akibat fluktuasi dari kecepatan angin. Adapun sebaran tertinggi berada pada titik bundaran ITDC dan patung bima dikarenakan bundaran ITDC merupakan area yang berdekatan dengan akses keluar masuk kawasan ITDC sehingga aktivitas trasnportasi yang tinggi terjadi di area ini. Titik patung bima merupakan area yang berada di area perhotelan dan merupakan area yang berdekatan dengan sumber emisi genset, boiler dan aktivitas perhotelan lainnya. Hal ini sejalan dengan penelitian yang 
menyebutkan bahwa konsentrasi parameter udara dipengaruhi oleh kendaraan bermotor, emisi gas buang industri dan aktivitas manusia (Ismiyati,2014; Juliasari \& Fatkhurrahman, 2014; Kroll, 2020).

Pola sebaran konsentrasi parameter debu total terlihat berbeda dibandingkan dengan parameter lainnya. Pada masa normal, sebaran tertinggi berada pada titik bundaran ITDC dan patung bima sedangkan pada masa pandemi Covid-19 sebaran tertinggi berpindah ke titik peninsula beach. Hal ini disebabkan karena pada masa normal debu yang terbentuk sebagian besar berasal dari emisi gas buang sumber bergerak dan tidak bergerak yang bereaksi membentuk partikel (Kroll, 2020). Sedangkan pada masa pandemi Covid-19 dan normal baru, aktivitas perhotelan berkurang sehingga menyebabkan konsentrasi debu di area bundaran ITDC dan patung bima juga berkurang. Tingginya sebaran debu dititik peninsula beach timbul akibat debu yang berasal dari area terbuka di sekitar pantai.

Berdasarkan pembahasan tersebut diatas, diketahui bahwa penelitian ini menemukan bahwa aktivitas masyarakat berpengaruh terhadap kualitas udara ambien. Hal ini dapat dijadikan sebagai dasar oleh pembuat kebijakan baik itu pemerintah ataupun ITDC dalam hal pengelolaan lingkungan yang berkelanjutan. Pemerintah Kabupaten/Kota melalui dinas terkait dapat melakukan penerapan aturan yang berlaku secara utuh terkait dengan ijin, pembinaan dan pengawasan dalam bidang pengelolaan lingkungan khususnya terkait dengan pencemaran udara. Penelitian ini juga menemukan bahwa dengan menggunakan SIG dapat dibuat suatu pemodelan untuk memetakan sebaran spasial kualitas udara ambien pada suatu kawasan. Dengan demikian temuan penelitian ini mempunyai implikasi teoritis yang nyata terhadap ilmu pengetahuan terkait dengan lingkungan.

Adapun keterbatasan dalam penelitian ini adalah bahwa penelitian ini hanya terbatas pada pengukuran kualitas udara ambien dengan menggunakan teknik midget sampler method. Titik sampling pada penelitian ini merupakan titik yang sudah ditentukan oleh pihak ITDC dalam rangka pemenuhan kebutuhan dokumen PROPER yang selama ini rutin dilakukan setiap tahun. Data kualitas udara masa pandemi Covid-19 terbatas hanya dilakukan dua kali dikarenakan data tersebut merupakan data sekunder. Selain itu data faktor meteorologi yang digunakan merupakan data meteorologi sesaat yang diambil bersamaan dengan proses pengambilan sampel kualitas udara.

Terlepas dari keterbatasan tersebut, penelitian ini diharapkan dapat memberikan kontribusi pada penelitian lebih lanjut terkait kualitas udara dan faktor yang mempengaruhinya. Penelitian ini juga diharapkan dapat berkontribusi terhadap pemerintah dan masyarakat/ stakeholder dalam bidang perencanaan, pengelolaan lingkungan dan tata guna lahan.

\section{SIMPULAN DAN SARAN}

\subsection{Simpulan}

Kualitas udara ambien di kawasan ITDC Nusa Dua Bali selama masa pandemi Covid-19 dan normal baru dibandingkan dengan masa normal berbeda nyata. Perbedaan kualitas udara ambien ini terlihat pada konsentrasi $\mathrm{SO}_{2}, \mathrm{NO}_{2}, \mathrm{CO}$, debu total dan $\mathrm{H}_{2} \mathrm{~S}$ selama masa pandemi Covid-19 dan normal baru mengalami penurunan dan konsentrasi $\mathrm{O}_{3}$ mengalami kenaikan dibandingkan dengan masa normal. Konsentrasi $\mathrm{NH}_{3}$ selama masa pandemi Covid-19 tidak berbeda nyata dibandingkan dengan masa normal dan normal baru. Meskipun demikian konsentrasinya selama masa pandemi 
Covid-19 dan normal baru cenderung menurun dibandingkan selama masa normal.

Faktor meteorologi suhu, kelembaban, dan curah hujan tidak berpengaruh terhadap kualitas udara ambien di kawasan ITDC Nusa Dua Bali selama masa normal, pandemi Covid-19 dan normal baru. Kecepatan angin tidak berpengaruh terhadap kualitas $\mathrm{SO}_{2}, \mathrm{NO}_{2}$, $\mathrm{NH}_{3}, \mathrm{H}_{2} \mathrm{~S}, \mathrm{CO}$ dan debu total namun berpengaruh negatif terhadap $\mathrm{O}_{3}$.

Peta sebaran spasial parameter $\mathrm{SO}_{2}$, $\mathrm{NO}_{2}, \mathrm{NH}_{3}, \mathrm{O}_{3}, \mathrm{CO}$ dan $\mathrm{H}_{2} \mathrm{~S}$ di kawasan ITDC Nusa Dua Bali pada masa normal, pandemi Covid-19 dan normal baru terlihat bahwa sebaran konsentrasi terendah berada pada titik peninsula sedangkan sebaran tertingginya berada di titik bundaran ITDC, patung bima maupun tersebar di kedua titik tersebut sekaligus. Pola sebaran debu total selama masa normal berbeda dengan masa pandemi Covid-19 dan new normal dimana pada masa normal sebaran tertinggi berada di titik bundaran ITDC dan patung bima sedangkan pada masa pandemi Covid-19 dan normal baru berada dititik peninsula beach.

\subsection{Saran}

1. Pemerintah melalui Dinas terkait disarankan untuk melakukan pengawasan terhadap pemantauan kualitas udara ambien dan emisi gas buang baik dari sumber bergerak ataupun tidak bergerak dengan menempatkan stasiun monitoring kualitas udara ambien otomatis pada beberapa lokasi yang merupakan daerah urban dan mewakili tata guna lahan.

2. Disarankan untuk dilakukan penelitian lebih lanjut terkait inventarisasi emisi guna mengidentifikasi sumber pencemar udara dan memperkirakan jumlah spesifik pencemar di kawasan ITDC Nusa Dua Bali.

\section{DAFTAR PUSTAKA}

Badan Pusat Statistik Provinsi Bali. 2020. Banyaknya wisatawan bulanan ke Bali 2004-2020. Diakses tanggal 30 Januari 2020 dari https://bali.bps.go.id/subject/16/pari wisata.html\#subjekViewTab3

Badan Standardisasi Nasional. 2005a. Udara ambien-Bagian 6: Penentuan lokasi pengambilan contoh uji pemantauan kualitas udara ambien. Jakarta: Badan Standardisasi Nasional.

Badan Standardisasi Nasional. 2005b. Udara ambien-Bagian 1: Cara uji kadar amoniak $\left(\mathrm{NH}_{3}\right)$ dengan metode indofenol menggunakan spektrofotometer. Jakarta: Badan Standardisasi Nasional.

Badan Standardisasi Nasional. 2017a. Udara ambien-Bagian 2: Cara uji kadar nitrogen dioksida $\left(\mathrm{NO}_{2}\right)$ dengan metode Griess-Saltzsmann menggunakan spektrofotometer. Jakarta: Badan Standardisasi Nasional.

Badan Standardisasi Nasional. 2017b. Udara ambien-Bagian 7: Cara uji kadar sulfur dioksida $\left(\mathrm{SO}_{2}\right)$ dengan metode pararosanillin menggunakan spektrofotometer. Jakarta: Badan Standardisasi Nasional.

Badan Standardisasi Nasional. 2017c. Udara ambien-Bagian 8: Cara uji kadar ozon dengan metode neutral buffer kalium iodida (NBKI) menggunakan spektrofotometer. Jakarta: Badan Standardisasi Nasional.

Badan Standardisasi Nasional. 2018. Pengukuran kadar hidrogen sulfida di udara tempat kerja dengan metode biru metilen menggunakan spektrofotometer visibel. Jakarta: Badan Standardisasi Nasional. 
ESRI. 2020. An Overview of The Raster Interpolation Toolset. Diakses tanggal 28 Maret 2021 dari https://desktop.arcgis.com/en/arcma p/latest/tools/3d-analyst-toolbox/anoverview-of-the-rasterinterpolation-toolset.htm.

Gautam, S. 2020. COVID-19: air pollution remains low as people stay at home. Air Quality, Atmosphere, \& Health, 1. https://link.springer.com/content/pdf /10.1007/s11869-020-00842-6.pdf

Hyperkes Bali. 2018. Instruksi Kerja Metode. Bali: UPTD. Balai Hyperkes \& KK Dinas Ketenagakerjaan dan ESDM Provinsi Bali.

Ismiyati, I., Marlita, D. and Saidah, D. 2014. Pencemaran udara akibat emisi gas buang kendaraan bermotor. Jurnal Manajemen Transportasi \& Logistik, 1(3),pp.241-248. https://journal.itltrisakti.ac.id/index. php/jmtranslog/article/view/23

ITDC. 2020. The Nusa Dua. Diakses tanggal 21 Januari 2021 dari https://www.itdc.co.id/portofolio/the -nusa-dua

Juliasari, I.R. and Fatkhurrahman, J.A.. 2014. Karakteristik Cerobong Boiler Industri di Propinsi Jawa Tengah Sebagai Bentuk Upaya Pentaatan Pengelolaan Lingkungan. Jurnal Riset Teknologi Pencegahan Pencemaran Industri, 5(2), pp.5158.

http://jrtppi.id/index.php/jrtppi/articl e/view/32/25

Kroll, J. H., Heald, C. L., Cappa, C. D., Farmer, D. K., Fry, J. L., Murphy, J. G., \& Steiner, A. L. 2020. The complex chemical effects of COVID-19 shutdowns on air quality. Nature Chemistry, 12(9), 777-779. https://www.nature.com/articles/s41 557-020-0535-Z

Marhaeni, A.D.R., 2018. Pengaruh Faktor Meteorologi Terhadap Fluktuasi Konsentrasi Pm 10 Dan O 3 Di Dki Jakarta. Institut Pertanian Bogor. Intitut Pertanian Bogor.

Nakada, L. Y. K., \& Urban, R. C. 2020. COVID-19 pandemi Covid-19c: Impacts on the air quality during the partial lockdown in São Paulo state, Brazil. Science of The Total Environment, 139087. https://reader.elsevier.com/reader/sd /pii/S0048969720326048?token=82 1ED2200A77AB963ED684965B30 53DCEEABEAE14CF469D06176F A5603E5E0703E712221F4BFB63A 6172E695CA58CD3E

Tobías, A., Carnerero, C., Reche, C., Massagué, J., Via, M., Minguillón, M. C., \& Querol, X. 2020. Changes in air quality during the lockdown in Barcelona (Spain) one month into the SARS-CoV-2 epidemic. Science of the Total Environment, 138540.

Turyanti, A., 2011. Analisis Pengaruh Faktor Meteorologi Terhadap Konsentrasi Pm10 Menggunakan Regresi Linier Berganda (Studi Kasus: Daerah Dago Pakar Dan Cisaranten, Bandung) Analysis Of The Influence Of Meteorological Factors To Pm10 Concentration Using Agromet, 25(1), pp.29-36. https://jurnal.ipb.ac.id/index.php/agr omet/article/view/6419/4961

Zangari, S., Hill, D. T., Charette, A. T., \& Mirowsky, J. E. 2020. Air quality changes in New York City during the COVID-19 pandemi Covid19c. Science of The Total Environment, 140496. https://www.sciencedirect.com/scien ce/article/pii/S0048969720340183 